\title{
SOME BIOCHEMICAL CHANGES IN NAPHTHALENE CATARACT*
}

\author{
BY \\ DORRIT SALMONY \\ Ophthalmological Research Unit (Medical Research Council), \\ Institute of Ophthalmology, London
}

LITTLE is known of the mechanism of the development of senile cataract in man, but it is generally assumed that it is due to a disturbance of the metabolism of the lens. The difficulties in attacking such a problem are great, but the experimental production of cataract with specific agents offers a favourable approach. Naphthalene was chosen for the present study, the ability of which to produce lens opacities in rabbits has been known since the work of Bouchard and Charrin (1886). It may be noted that, in general, the histological changes associated with this type of cataract resemble closely those seen in senile cataract in man.

It can be assumed that the cataractous change produced by feeding naphthalene to the experimental animal is due to some interference with the metabolism of the lens by this toxic agent. A pointer to this interference may be the presence of a high concentration of lactic acid in such lenses, a unique feature of naphthalene cataract, distinguishing it from all other types of experimentally-produced cataract. This was initially reported by Müller (1939), who found that the lactic acid content of the lens increased by 70 per cent. 12 to 48 hours after the administration of naphthalene to rabbits by stomach tube, a finding confirmed by Nordmann and Mandel (1952) in studies in vitro, using lenses from rabbits which had been fed naphthalene for 2 days. These authors found an increase of 86 per cent. above the normal in the production of lactic acid by these cataractous lenses after incubation at $37^{\circ} \mathrm{C}$. for 1 hour.

It was thought that an investigation of some of the enzymes concerned with the metabolism of lactic and pyruvic acid in normal and cataractous lenses might provide an explanation for this increase. The three enzymes chosen in this preliminary investigation are lactic dehydrogenase, glyoxalase, and malic enzyme. Lactic dehydrogenase catalyses the reversible reduction of pyruvic acid to lactic acid, glyoxalase the production of lactic acid from methyl glyoxal, and malic enzyme the oxidative decarboxylation of pyruvic acid to malic acid.

\section{Methods}

4-month-old rabbits weighing approximately $2 \mathrm{~kg}$. were used for all experiments. In order to produce cataracts, it was necessary to feed the rabbits with bran and carrots rather than the usual cabbage diet for at least one week before the experiments were started. It has been suggested that a high blood calcium level, obtained

\footnotetext{
* Received for publication March 25, 1959
} 
by feeding cabbage and oats, reduces cataract formation, whereas the absorption of calcium is low when the rabbits are given bran and carrots instead (Bourne and Campbell, 1933). The rabbits were given $2 \mathrm{~g}$. naphthalene dissolved in liquid paraffin daily by stomach tube. After 24 hours peripheral striations appeared which gradually increased in size, the lenses becoming opaque after approximately 7 days.

Preparation of Lens Extracts.-The lenses were dissected out, and immediately dropped into ice-cold water. They were then gently dried on filter paper, weighed, and homogenized by grinding in a mortar containing glass-distilled water and a small quantity of washed powdered glass. The homogenate was quantitatively transferred into a graduated centrifuge tube and centrifuged to remove powdered glass and broken cells; the supernatant was used for determinations of enzyme activity.

Enzyme activities are expressed in terms of wet weight of lens, since there was no significant difference in the Wet Weight/Dry Weight ratio of normal compared with cataractous lenses.

Lactic Dehydrogenase Activity.-This was determined spectrophotometrically by the method of Horn and Bruns (1956).

$2 \mathrm{ml}$. glycine-semicarbazide buffer, $\mathrm{pH} 10.5$ (3 g. glycine and $2.5 \mathrm{~g}$. semicarbazide hydrochloride made up to $50 \mathrm{ml}$.), $0 \cdot 2 \mathrm{ml}$. 0.1 M Li lactate, $0.2 \mathrm{ml}$ DPN (Diphosphopyridine nucleotide) $(100 \mathrm{mg} . / 10 \mathrm{ml}$.), and water to a final volume of $3 \mathrm{ml}$. were pipetted into a $1-\mathrm{cm}$. spectrophotometer cell. The reaction was started by addition of 0.05 to $0.1 \mathrm{ml}$. lens homogenate. The increase in density caused by the reduction of DPN was used as a measure of enzyme activity. Readings were taken at $366 \mathrm{~m} \mu$ at 30-sec. intervals for 10 min., against a blank containing no DPN.

Glyoxalase Activity.-This was measured manometrically by the Warburg technique, according to Crook and Law (1952).

Lactic acid production from methyl glyoxal is determined by measuring the carbon dioxide liberated from bicarbonate buffer by the acid. The main compartment of the Warburg flasks contained $0.4 \mathrm{ml} .0 .2 \mathrm{M} \mathrm{NaHCO}, 0.2$ to $0.3 \mathrm{ml}$. lens homogenate, and water to a final volume of $3 \mathrm{ml}$., and the side-arm contained $0.2 \mathrm{ml} .1 .5$ per cent methyl glyoxal, adjusted to $\mathrm{pH} 7 \cdot 0$, and $0.2 \mathrm{ml} .(2.5 \mathrm{mg})$ glutathione. The fluid in the vessels was equilibrated with 95 per cent. $\mathrm{N}_{2} / 5$ per cent. $\mathrm{CO}_{2}$, and carbon dioxide evolution was measured for 30 mins. at $25^{\circ}$. Controls contained no enzyme or substrate.

Malic Enzyme.-This was determined by the method described by van Heyningen and Pirie (1953).

Two lenses were ground up in approximately 3 to $4 \mathrm{ml}$. glass-distilled water in a mortar. The homogenate was left at room temperature for $30 \mathrm{~min}$., dialysed against running tapwater for 24 to 30 hours, and then centrifuged. The enzyme activity of the supernatant was measured spectrophotometrically by following the reduction of TPN at $340 \mathrm{~m} \mu$. Each spectrophotometer cell contained $1.5 \mathrm{ml}$. M/35 veronal buffer, $\mathrm{pH} 7 \cdot 4 ; 0.1 \mathrm{ml}$. $(0.28 \mu \mathrm{mol}) \mathrm{TPN}, 0.2 \mathrm{ml} .10^{-2} \mathrm{M} \mathrm{MnCl}_{2}, 0.3 \mathrm{ml} .10^{-2} \mathrm{M} \mathrm{Na}$ malate, enzyme, and water to a final volume of $2.5 \mathrm{ml}$. Controls contained no TPN. Readings were taken at 30-sec. intervals, for $10 \mathrm{~min}$. 
Results and Discussion

Lactic Dehydrogenase Activity.-Lactic dehydrogenase catalyses the reversible oxidation of lactic acid to pyruvic acid in the presence of DPN as coenzyme. The activity of this enzyme, determined spectrophotometrically by measuring the increase in density caused by the reduction of DPN to DPNH was compared in homogenates prepared from normal and cataractous lenses. The increase in density for the first 4 minutes was used as a measure of enzyme activity; it was found that the rate of reaction was linear for 6 minutes, after which it gradually decreases. Only lenses in the early stages of cataract, all of which had developed peripheral striations but no gross opacities, were used for these experiments.

Table I shows a definite decrease in the lactic dehydrogenase activity of cataractous compared with normal lenses. This remains more or less constant for 4 days, during which the rabbits received a dose of $2 \mathrm{~g}$. naphthalene every day, after which the enzyme activity was further diminished.

TABLE I

LACTIC DEHYDROGENASE ACTIVITY OF NORMAL AND CATARACTOUS LENSES

\begin{tabular}{|c|c|c|c|c|}
\hline \multicolumn{2}{|c|}{ Lenses } & \multirow{2}{*}{$\begin{array}{l}\text { No. of Doses } \\
\text { of Naphthalene }\end{array}$} & \multirow{2}{*}{$\begin{array}{l}\text { Increase in Density/ } \\
4 \mathrm{~min} . / 100 \mathrm{mg} . \text { wet wt. } \\
\text { lens }\end{array}$} & \multirow{2}{*}{$\begin{array}{l}\text { Per Cent. } \\
\text { Decrease }\end{array}$} \\
\hline Type & Number & & & \\
\hline Normal & 4 & & $1 \cdot 44$ & \\
\hline Cataractous & $\begin{array}{l}4 \\
2 \\
2 \\
2 \\
2\end{array}$ & $\begin{array}{l}1 \\
2 \\
3 \\
4 \\
5\end{array}$ & $\begin{array}{l}0.83 \\
0.84 \\
0.84 \\
0.83 \\
0.51\end{array}$ & $\begin{array}{l}42 \\
41 \\
41 \\
42 \\
65\end{array}$ \\
\hline
\end{tabular}

Coenzyme Specificity of Lactic Dehydrogenase.-It is known that lactic dehydrogenase is normally a DPN-dependent enzyme. In order to determine whether it is also capable of functioning with TPN, as has been shown by Kinoshita (1957) in the case of ox corneal epithelium, TPN was substituted for DPN in the enzyme determination. It was demonstrated (Table II) that TPN can be reduced, although the same amount of enzyme reduced only approximately one-sixth as much TPN as DPN, under identical conditions.

TABLE II

LACTIC DEHYDROGENASE ACTIVITY WITH DPN AND TPN AS COENZYMES (CONDITIONS AS FOR TABLE I)

\begin{tabular}{c|c}
\hline Addition & Increase in Density/4 min./100 mg. wet wt. \\
\hline $2 \mathrm{mg}$. DPN & 1.44 \\
$2 \mathrm{mg}$. TPN & 0.24 \\
\hline
\end{tabular}


Lactic dehydrogenase has several functions in the metabolism of the lens. As well as controlling the actual amount of lactic acid present in the lens, it is believed to play some part in maintaining TPN, which is required for the oxidative metabolism of hexose phosphates, in the oxidized state. It has thus been demonstrated (Kinoshita, 1957) that the lactic dehydrogenase of ox corneal epithelium can use TPN as well as DPN as coenzyme. Since the cytochrome system which is the usual method of re-oxidation of TPNH is thought to be rather inadequate in the lens, the author proposed that TPNH formed during the oxidation of glucose-6-phosphate via the hexose-monophosphate shunt can be re-oxidized by lactic dehydrogenase. Since it has now been shown that lenticular lactic dehydrogenase is also capable of functioning with TPN, it appears possible that here, too, TPNH is re-oxidized by a similar mechanism.

A decrease in lactic dehydrogenase activity could therefore affect not only the lactic acid concentration but indirectly also the oxidation of glucose by the hexose-monophosphate shunt, which has been shown to play an important role in the oxidative metabolism of the lens (Kinoshita, 1955).

Glyoxalase.-This enzyme, which is very active in the lens, catalyses the conversion of methyl glyoxal to lactic acid, in the presence of glutathione as coenzyme.

The glyoxalase activity of normal lenses was found to be $269 \mu \mathrm{l} . \mathrm{CO}_{2} / 30$ min./100 mg. wet weight lens (Table III). No significant difference was found in the enzyme activity of lenses from rabbits which had been given naphthalene for 1 to 4 days.

TABLE III

GLYOXALASE ACTIVITY OF NORMAL AND CATARACTOUS LENSES

\begin{tabular}{l|c|c|c}
\multicolumn{2}{c|}{ Lenses } & $\begin{array}{c}\text { No. of Doses } \\
\text { of Naphthalene }\end{array}$ & $\mu 1 . \mathrm{CO}_{2} / 30$ min./100 mg. \\
wet wt. lens
\end{tabular}

Malic Enzyme.-This is responsible for the interconversion of malic acid and pyruvic acid, and requires TPN as coenzyme. The equilibrium of this reaction is known to be in favour of pyruvic acid. This is another enzyme which could, indirectly, determine to some extent the amount of lactic acid in the lens. 
The reduction of TPN is used as a measure of enzyme activity. The rate of reduction during the first $2 \mathrm{~min}$. was measured, since the increase in density at $340 \mathrm{~m} \mu$ with time was linear for only 4 to $6 \mathrm{~min}$. in most experiments. Results are expressed as "increase in density/2 min./100 mg. wet wt. lens". Table IV shows that the enzyme activity of homogenates prepared from normal lenses was $0.039 / 100 \mathrm{mg}$. wet wt. $2 \mathrm{~min}$., and ranged from 0.029 to 0.013 for cataractous lenses.

TABLE IV

MALIC ENZYME ACTIVITY OF NORMAI. AND CATARACTOUS LENSES

\begin{tabular}{|c|c|c|c|c|}
\hline \multicolumn{2}{|c|}{ Lenses } & \multirow{2}{*}{$\begin{array}{l}\text { No. of Doses } \\
\text { of Naphthalene }\end{array}$} & \multirow{2}{*}{$\begin{array}{l}\text { Increase in Density/ } \\
2 \text { min./100 mg. wet wt. } \\
\text { lens }\end{array}$} & \multirow{2}{*}{$\begin{array}{l}\text { Per Cent. } \\
\text { Decrease }\end{array}$} \\
\hline Type & Number & & & \\
\hline Normal & 4 & & 0.039 & \\
\hline Cataractous & $\begin{array}{l}4 \\
3 \\
3\end{array}$ & $\begin{array}{l}1 \\
2 \\
4\end{array}$ & $\begin{array}{l}0.029 \\
0.019 \\
0.013\end{array}$ & $\begin{array}{l}25 \cdot 6 \\
51 \cdot 3 \\
66 \cdot 6\end{array}$ \\
\hline
\end{tabular}

In all the lenses examined, it was found that as the cataract progressed, so the activity of malic enzyme diminished.

A decrease in the activity of malic enzyme will not only tend to lower the pyruvate concentration, although the production of pyruvic acid will be controlled mostly by the breakdown of carbohydrate, but also to alter the equilibrium of all other systems in which pyruvate is an intermediate.

It is not possible at this stage to explain the cause of the large increase in lactic acid present in these cataractous lenses, since this will not solely depend on the activities of the various enzymes, but also on the concentration of the coenzymes and substrates, some of which are now being studied.

It appears unlikely, from the work which has been done so far, that the cataractous changes caused by feeding naphthalene are related to an inhibition, by naphthalene metabolites, of SH-enzymes, as has been shown for $x$-ray cataract by van Heyningen, Pirie, and Boag (1954). These authors found that, of the enzymes studied, those requiring free SH-groups progressively lost their activity, whereas others which are not dependent on SHgroups were normally active in opaque lenses. In naphthalene-induced cataract, however, glyoxalase, which is an SH-enzyme, was shown to be unchanged, whilst lactic dehydrogenase and malic enzyme, neither of which require free $\mathrm{SH}$ groups for their activity, are inhibited.

\section{Summary}

(1) Lactic dehydrogenase, glyoxalase, and malic enzyme activities have been compared in homogenates prepared from normal and cataractous lenses. 
(2) Glyoxalase activity was found to be unchanged after naphthalene administration for 1 to 4 days.

(3) Lactic dehydrogenase activity was decreased by approximately 40 per cent. in cataractous as compared with normal lenses.

(4) Malic enzyme was decreased by 25 per cent. after one dose of naphthalene. This was further decreased to 66 per cent. after 4 days.

I should like to thank Sir Stewart Duke-Elder for his interest and encouragement in this work, and Miss Andrea Read for valuable technical assistance.

\section{REFERENCES}

Bourne, M.C., and Campbell, D. A. (1933). Brit. J. Ophthal., 17, 220.

Bouchard and Charrin (1886). C. R. Soc. Biol., sér. 8, 3, 614.

CroOK, E. M., and LAW, K. (1952). Biochem. J., 52, 492.

Horn, H. D., and Bruns, F. H. (1956). Biochim. biophys. Acta, 21, 378.

Kinoshita, J. H. (1955). A.M.A. Arch. Ophthal., 54, 360.

- (1957). J. biol. Chem., 228, 247.

Müller, H. K. (1939). v. Graefes Arch. Ophthal., 140, 171.

Nordmann, J., and Mandel, P. (1952). Bull. Soc. belge Ophtal., No. 102, p. 524.

van Heyningen, R., and PIRIE, A. (1953). Biochem. J., 53, 436.

$\longrightarrow$, , and BOAG, J. W. (1954). Ibid., 56, 372. 